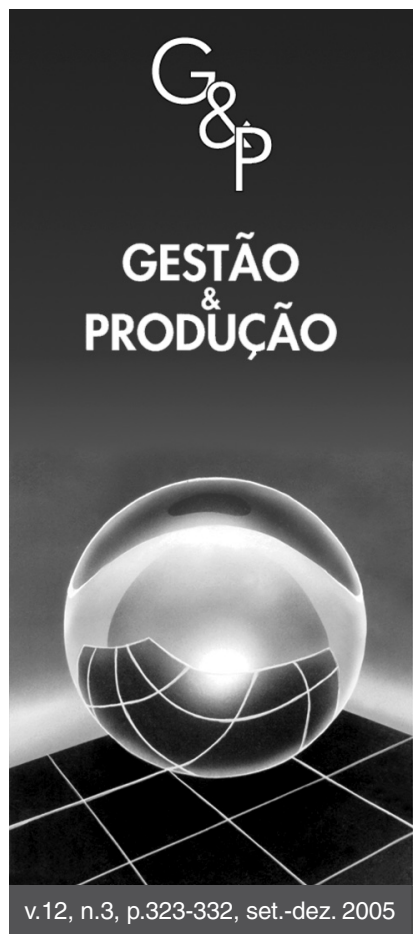

\title{
OPERATIONS STRATEGY: WILL IT EVER REALIZE ITS POTENTIAL?
}

Nigel Slack

Warwick Business School, University of Warwick, CV4 7AL, UK, e-mail: nigel.slack@wbs.ac.uk

Abstract

Although the last three decades have seen a steady rise in the perceived importance of operations strategy together with its corresponding literature base, one could argue that it has not yet reached its full potential. This paper reviews some of the reasons why this may be. It starts by briefly examining the importance of operations strategy within the broader operations management area and then examines some challenges to the subject under two headings. The first heading concerns whether operations strategy accurately reflects the nature of 'operations' within the economy. The second heading examines some of the challenges in making any operations-based topic into one that has strategic relevance. Finally, a number of prescriptions are put forward that may allow the development of the subject to answer some of the challenges posed.

Keywords: operations strategy, manufacturing operations, service operations, research trends.

\section{Introduction}

For years the concept of operations strategy seemed a contradiction in terms. Strategy is broad, long-term, aggregated, and the concern of the most senior management in the business. Operations, on the other hand, are detailed, complex, concerned with day-to-day issues, and carried out by those towards the lower levels of the organizational hierarchy. Yet this is to confuse operations with operational. Operational is indeed the opposite of strategic. But operations are the resources that create services and products, the parts of the business that satisfy customers' needs. But, arguably, what seems like a semantic difference has troubled the development of a clear operations strategy development trajectory. Academics and practitioners who believe that the study of operations is limited to operational matters are fundamentally misunderstanding the contribution of operations management to strategy and, more importantly, the huge potential that operations has to deliver sustainable competitive advantage.
Fortunately, the number of academics who make this mistake is rapidly declining. The number of powerful and increasingly well-articulated arguments that illustrate the contribution of operations to strategic success that have come from authors such as Skinner (1969), Hayes and Pisano (1996) etc., have convinced most of the importance of operations strategy. However, there are many practitioners and many businesses that either do not fully understand this argument or have yet to be convinced. And this must be counted, at least partially, as a failure of academic operations strategy. So, notwithstanding the significant growth of interest in the operations strategy area, it is worth at least posing the question of whether it could have had an even greater impact.

If, particularly amongst practitioners, the ideas and models of operations strategy are not broadly well-known, it is worth examining some of the many reasons for this. For example, one could argue that, as an idea, operations 
strategy is clear neither on what constitutes 'operations', nor on exactly how operations can have a strategic impact. This paper examines both of these issues. It will consider whether operations strategy really reflects the reality of operations within developed economies. Also it will examine the nature of the strategic contribution of operations strategy. In neither case does it provide a whole or comprehensive argument. However, it may contribute to the ongoing debate as to the role of operations strategy within the general body of knowledge of operations management. Firstly though, it will briefly look at the importance of operations strategy to the broader filed of operations management.

\section{How important is operations strategy?}

Following from the argument (above) that practitioners do not see operations strategy as representing the same degree of importance as does the academic community, it would be wise to search for evidence that either supports or challenges such an assertion. A simple search through the websites of the major consultancy firms reveals that a very significant majority of the topics and cases cited under 'operations' topics are more operational than strategic. Not surprisingly, these are dominated by topics recognizable to practicing managers such as 'process redesign', ERP, etc. Relatively little effort seems to be put into selling operations strategy solutions. Similarly, those firms offering strategy consultancy, although occasionally mentioning operations strategy, do not give it the prominence of more general strategy. One may conclude from this that these consultancy firms do not judge that there is a sufficiently large market for operations strategy per se.

At a more formal level, one recent study (Slack, Lewis and Bates, 2004) attempted to compare the topics covered in papers published in the two leading American and European operations management journals between 1990 and 2002, with some measures of practitioner prioritization. In doing so it was attempting to answer a simple but fundamental question, namely, does the research in operations management really reflect the perceived importance of particular topics? Using this journal data set, current research content priorities were established by classifying recent papers (i.e. 2000-2003) against a series of 16 generic topic headings (see Table 1). The percentage of these papers as a component of the total paper set is then used as a surrogate measure of relative research priority. Practitioner priorities were assessed from the data from an annual survey of MBAs at Warwick University. This survey originally reported in Slack et al. (2004) has now been extended to include more data and here covers the period (i.e. 2000-2005). Assessments of the importance of each of the 16 content topics were framed in terms of individual perceptions (based on previous industrial experience) of this 'subjects' impact on overall business performance: a five point scale was used. Table 1 presents the two sets of findings together, in rank order, to facilitate identification of any obvious similarities and disconnects.

There are clear limits to the validity and reliability of any findings from this analysis - especially with respect to the interpretative nature of the paper content classification process and the use of a narrowly-based sample (i.e.

Table 1. Comparison of Practitioner and Research Priorities.

\begin{tabular}{cllc}
\hline $\begin{array}{c}\text { Mean practice } \\
\text { contribution score }\end{array}$ & $\begin{array}{l}\text { Ranked practice content } \\
\text { MBA Survey 2000-2005 }\end{array}$ & $\begin{array}{c}\text { Ranked research content Extract } \\
\text { from JOM + IJOPM 2000-2003 }\end{array}$ & $\begin{array}{c}\text { Combined mean \% } \\
\text { papers }\end{array}$ \\
\hline 4.51 & Quality \& Improvement & Operations strategy & 20.25 \\
4.44 & Supply chain & Supply chain & 14.93 \\
4.15 & JIT/lean & Quality \& Improvement & 10.45 \\
4.00 & MRP/ERP & Performance measurement & 7.14 \\
3.97 & Planning \& control & Process technology & 6.63 \\
3.69 & Process design & Product/service design & 6.45 \\
3.35 & Operations strategy & Job design & 5.06 \\
3.33 & Capacity & JIT/lean & 3.97 \\
3.12 & Performance measurement & Planning \& control & 3.75 \\
3.00 & Inventory & Process design & 2.64 \\
3.00 & Product/service design & Inventory & 1.86 \\
3.00 & Process technology & Failure/risk & 1.49 \\
2.85 & Job design & Maintenance & 0.81 \\
2.58 & Failure/risk & Capacity & 0.63 \\
1.92 & Maintenance & Layout & 0.33 \\
1.63 & Layout & MRP/ERP & 0.31 \\
\hline
\end{tabular}


age, education profile, European bias, etc.) of practitioner perceptions, yet even accepting once again that they are, at best, indicative findings, some interesting observations can be made. For example, there are several topics that appear to have generated an equivalent level of practice and research interest, supply chain issues, for example. There are also topics that practitioners appear to ascribe a greater significance than academics. For instance, JIT/ lean production is a long-established operations management research priority that in recent years has probably become less prominent as a subject as the core principles have matured. In terms of practice

There are also some topics where practitioner interest appears to strongly lag academic priorities. For instance, operations strategy is the most popular research priority and yet it ranks six places above its practice score. The explanations for this may lie in the limitations of the research method: for example, it is much more challenging to articulate (on a single five-point scale) the 'contribution' of an amorphous construct like an operations strategy than a widely shared notion like quality. At the same time, we should also entertain the possibility that these ideas remain intellectually interesting rather than practically relevant.

\section{Moving operations strategy to really reflect 'operations'}

It may be that one reason for the relatively low practitioner interest in operation strategy is because, as a subject area, it does not really reflect 'operations' as they exist within the business world. One could argue that 'true' operations strategy is neither taught nor researched within the vast majority of business schools. Often, what is both taught and researched is manufacturing strategy. The earliest influences on operations strategy (Skinner, 1969; Hayes and Wheelwright, 1984; Hill, 1984) were all essentially manufacturing strategy works. The issue here is whether 'operations' and 'manufacturing' are the same thing. To answer this one must go back to when the subject started using the term 'operations' during the 1970s, when prior to being called 'operations management' it was seen as very much associated with the manufacturing sector (Slack et al., 2006). In fact it would have been called 'production' or 'manufacturing' management, and was concerned exclusively with the core business of producing physical products. Starting in the 1970s and 1980s the term operations management became more common. It was used to reflect two trends. First, and most importantly, it was used to imply that many of the ideas, approaches and techniques traditionally used in the manufacturing sector could be equally applicable in the production of services. The second use of the term was to expand the scope of 'production' in manufacturing companies to include, not just the core processes that directly produce products, but also the non-core production-related processes that contribute to the production and delivery of product. This would include such processes as purchasing, physical distribution, after sales service, and so on. More recently the term operations and process management (or sometimes just process management) has been used to denote the shift in the scope of the subject to include the whole organization. It is a far wider term than operations management because it applies to all parts of the organization. This latter trend itself presents a challenge to operations strategy. All types of services (including 'internal' services such as Human Resources Management) have become more concerned about their levels of productivity, quality, responsiveness, etc (Levitt 1972, etc.). As a result, the audiences for process management and reengineering courses, books and consultancy, are no longer limited to functional operations managers. Increasingly, all sorts of administrative personnel and managers see themselves as managing processes and therefore have something to learn from operations strategy ideas (Womack and Jones 1994; 1996). But, can the subject embrace an examination of the operations function in both manufacturing and service sectors, and also the management of processes in operations and non-operations functions?

\section{Is operations strategy biased towards the manufacturing sector?}

Again, it is important to search for evidence that operations strategy does not reflect the nature of economic activity. The same study quoted earlier (Slack, Lewis and Bates, 2004) also examined the sectoral settings of operations papers and compared these with the relative importance of manufacturing and service sectors in the US and European economies. Of course, one could argue that both US and European economies have moved further in the direction of post-industrialization in the sense that their service sectors are relatively well developed. Yet, while this is true, in very few economies is the manufacturing sector dominant. Even in developing economies, manufacturing does not represent the majority of economic activity.

The research attempted to establish a 'broad-brush' indication of the percentage contribution of each sector to overall economic activity (i.e. GDP), while accepting that any sector-specific classification of economic activity is not straightforward because economic institutions use different categories and economic measures. The data still revealed some important and supportable sectoral issues that should influence the operations strategy research agenda. In particular, manufacturing, at around $17 \%$ of total economic activity, is an important 
but, in itself, relatively small part of both the US and UK economies - other individual categories like government, financial and retail services contribute at least as much, if not more, to GDP as the manufacturing sectors. Taken as a whole, those activities which broadly constitute services are very significantly more important in terms of economic activity than even an expanded definition of primary economic activity (i.e. manufacturing, construction, mining and utilities, etc.).

In order to make an assessment of the extent of any gap between economic and operations research activity, the sectoral focus of papers published in the two journals was examined. Of course, the presumption that papers published in just two journals, no matter how prestigious, broadly reflect the totality of operations research (or even the different balance of European and US research: Drejer et al., 2000) is debatable - especially given the emergence of service sector journals in the last decade (e.g. the International Journal of Service Industry Management). Moreover, the review and publication lead-times associated with journals often means that published work lags current research concerns. Yet, it still offers an insight. Specifically, only those papers which offered some kind of sectoral examples (even if anecdotal) were included because they could then be categorized as being: 1) set in a manufacturing context; 2) set in a service context; or 3) set in a generic content (i.e. spanning both manufacturing and service exemplars).

Although the data showed a trend in both journals away from manufacturing dominance, $66.15 \%$ of IJOPM and $49.43 \%$ of JOM papers were classified as set in a manufacturing context and only $7.64 \%$ of IJOPM and $12.87 \%$ of JOM papers were classified as set in a service context. Even using the 2002 data, $49.37 \%$ of IJOPM and $39.44 \%$ of JOM papers were classified as set in a manufacturing context and $15.19 \%$ of IJOPM and $28.17 \%$ of JOM papers (n.b. including a special edition dedicated to service design) were classified as set in a service context. Given the GDP data, this seems to offer strong support for the proposition that there is a sectoral priority gap between operations research and economic activity. Of course this need not necessarily imply a criticism of operations research: one could make a case that researchers should not simply follow economic activity but rather make their own judgments about what is really important. Several studies argue in favour of a bias towards manufacturing research because this sector remains disproportionately strategically important and/or is peculiarly rich in terms of its operations issues. Yet one cannot escape the conclusion that, at the very least, it should give cause for some critical reflection that more than $80 \%$ of operations activity has, over the last 14 years, accounted for only about $10 \%$ of operations research.
The above data relates to operations research as a whole rather than operations strategy research specifically. Although not analyzed in the original paper, the data collected showed an even greater bias towards manufacturing-related research within the operations strategy area. Again, this could be partly explained by the existence of specialist service-related journals. It may also be a function of the fact that service management is often taught and researched in marketing rather than operation groups within business schools in several parts of the world. Yet, the absolute imbalance between the figures still leads one to the conclusion that, if operations strategy is being developed within a service context, it would have a far greater presence within the two leading operations journals.

\subsection{The 'servitization' of manufacturing}

Although academic work has remained overly biased towards manufacturing, there is a 'practitioner' trend that tells a different story. This is because products and services are merging. Increasingly, product manufacturers are seeking either to grow or protect their profitability by enhancing the service elements of their customer offerings. Within the manufacturing sector, the lack of serious development in service strategy is impairing operations strategy's contribution. For example, arguably, one of the most significant trends in manufacturing, especially in complex, high worth capital goods, is the trend towards 'servitization'. Servitization is the generic (if somewhat unattractive) term that has come to mean any strategy that seeks to change the way in which product functionality is delivered to its markets. This is a powerful concept and one that seems to offer a lifeline to many manufacturers under competitive pressure. An example comes from the aerospace sector. Complex aerospace products such as civil and military aircraft are triumphs of systems engineering, and more specifically, systems integration. Although originally developed independently, engine management systems, navigation systems, landing systems, instrumentation systems, and so on, are increasingly integrated within the aircraft platform to provide higher degrees of product sophistication. At the same time the companies that make these aircraft are becoming aware of the value of the servitization of their products (e.g. Oliva and Kallenberg, 2003). That is, marketing the capability that their products bring. So, for example, in aero engine manufacture, Rolls Royce used the phrase "power by the hour" to denote its ability to sell hours of flying capability rather than an aircraft engine alone. The ability to do this requires the coordination of manufacturing systems, maintenance systems, spare parts supply systems, logistics systems, and so on. These individual operations processes need to be integrated in the same way as the 
physical systems that make up its products have been integrated. Again, the underlying technical knowledge on which products themselves have been developed over the years has become significantly relevant in the development of the operations processes that enable them to be delivered into the market. But, this depends on the application of these ideas into a practical business context.

"Services have also developed in the manufacturing industry. The traditional boundary between manufacturing and services is becoming more and more blurred....the role of service in providing value is even more important. Not long ago, most of a product's added value came from the production processes that transformed raw materials into products. Now there is added value from technological improvements, intellectual property, product image and name brands, aesthetic design and styling that only services can create....therefore there is an increased interest amongst manufacturing industries in putting less emphasis on producing products and more interest in adding value to a customer through the provision of a service that helps them to extend the spectrum of their products." (Mont, 2000). However, in order to more critically appraise the servitization concept it will be necessary to further investigate the emerging key components of the process. In particular, it is important to distinguish the reality of implementing servitization strategies from the more rhetorical pronouncements starting to become evident, both in the popular management press and amongst the consultancy community.

Although small, the literature in the servitization area is growing. However, much of the academic literature is naive in its understanding of organizational complexity and limited in its perspective (often confined to single dyadic relationship). Early studies on industrial service providers concentrated largely on spare parts manufacture and simple maintenance provision (Wise and Baumgartner, 1999). Later work increasingly concentrated on the integration of products and service as the context in which industrial service providers could be developed, particularly in terms of how product manufacturers seek either to grow or protect their profitability by enhancing the service element of their customer offerings. This is why most literature assumes that, product manufacturers increasingly are seeking, either to grow, or protect their profitability by enhancing the service elements of their customer offerings (Matthyssens and Vandenbempt, 1998; Wise and Baumgarter, 1999). Thus the emergence of a wide variety of strategies based on "blend[s] of services with products, and vice-versa, [that are] increasingly common" (White et al., 1999).

Servitization is clearly more than a management fad. It is an important indicator of the way in which many in- dustries are likely to develop. It is a movement along the trajectory of economic development that could enable the bulk of value capture to remain in developed economies, even when manufacturing itself moves to less developed economies. However, what seems to be clear, even at this stage, is that servitization is not without its challenges. These include coping with the differences between 'efficiency' and 'value-creating' drivers, recognizing the difficulty of reconciling 'purchaser' and 'provider' requirements, adapting technology development trajectories to changed risk characteristics, and above all, updating the mindset of the firm to make the most of a service dominated environment.

One recent investigation (Slack, 2005) into the patterns of servitization presents the results from a study that investigated some of the emerging conceptual and practical opportunities as well as the threats that are associated with the servitization challenge in companies featuring servitization a variety of sectors. It reached the following conclusions.

The main motivation behind the strategy of moving towards servitization is largely based on revenue generation. This is especially true for organizations with a large installed base of products, but applies more broadly, particularly because services are regarded as having higher margins than products. In addition, services are regarded as providing a more stable source of revenue, less prone to less economic cycles, as well as having the ability to grow even in mature markets.

Customer motivation is primarily based on cost and (to a lesser extent) quality. By far the most important drivers for customer companies to outsourcing their services is to focus on their core business and reduce their overall cost base.

There will be a limit as to how far suppliers of service can improve profitability, while customers simultaneously save costs. Although most companies surveyed saw these two seemingly opposing factors being reconciled through the development of higher value services.

Servitization has two distinct dimensions - stretch and width. Stretch means the extent to which a company moves down the supply chain. Width means the number of service components offered to customers at each stage of the supply chain. It is likely that different patterns of servitization along these two dimensions will have implications for the nature of their implementation.

The concept of 'strategic fit' is a useful perspective in understanding the progress towards increasingly sophisticated integrated service packages. It also emphasizes some of the risks inherent in misaligned market requirements and service capabilities.

Servitization involves new and ill-understood risks. These include, the risks inherent in diverting financial re- 
sources away from other activities, the larger than expect cost of establishing service networks, and (for some companies) the cost of investing in market positioning.

Servitization involves significant cultural issues. In particular there is some doubt that, notwithstanding explicit policies to embrace servitization, some companies still think of themselves primarily as manufacturers with 'add on' services, rather than service companies whose offerings include manufactured products.

Servitization involves designing services, a task that is significantly different to designing products. Services, by their nature, are fuzzy and difficult to define. This has several implications particularly in the way services are perceived by customers, how service quality is defined, and how service innovation is managed.

Servitization involves significant organizational structuring choices. Most organizations have evolved using an organizational structure that separates out service from manufacturing divisions. But this structure may become increasingly inappropriate as the extent of servitization increases.

Servitization exposes costing deficiencies. In particular life cycle costing was seen as a very approximate activity that would have to be improved significantly if servitization was to avoid unacceptable risks.

Servitization may be limited by the extent of strategic span in the supply chain. Moving down the supply to provide service will inevitably increase strategic span unless some upstream activities are abandoned. The dilemma is for companies that derive competitive advantage through the embedded knowledge of their upstream activities.

Servitization emphasizes new relationship skills in the supply chain. Managing the supply chain where intangible services rather than physical products are traded requires a new set of supply chain relationship skills.

Servitization redefines risk management. There was significant anxiety regarding the unquantified but probably significant increase in risk in taking over activities previously performed by customers. It may be that at some point the marginal extra risk incurred will outweigh the marginal benefits of increased profit potential.

Servitization impacts technology strategy. The value of new but less reliable technologies is likely to decrease when servitization involves taking on more explicit risk.

Servitization involves integrating service processes. It is generally recognized that the integration of service processes posed different challenges to those involved in the integration of physical process.

Servitization poses new opportunities for knowledge transfer mechanisms. Generating knowledge is a key task, especially for front line staff, yet most companies were dissatisfied with their ability to feed back this knowledge, especially into product design activities.
While some of these emergent points are treated within the broad business strategy area, not all of them receive sufficient attention from a purely operations strategy perspective. So, there may be a case for arguing that not only is academic operations strategy failing to reflect the dominance of service activity in most economies, even when it treats manufacturing, it is ignoring the influence of service concepts within its traditional sector.

\section{Moving operations towards being 'stra- tegic'}

It is not difficult to justify the importance of the strategic perspective of 'operations' on the business as a whole. No other functional strategy has such a direct impact on both revenue and cost. The popularization of ideas such as TQM and lean production established in both practitioner and research arenas the idea that operations practice must pursue the twin objectives (even if to different extents) of improving aspects of service such as quality, variety, responsiveness etc., while at the same time reducing costs. Given the business maxim that "profit is a very small number made up of the difference between two very big numbers", any subject that claims to increase revenue and reduce costs must demand the attention of companies that can appreciate its potentially disproportionate effect on profitability. It is not surprising then that the cumulative contribution of operations strategy's conceptual development has been significant, especially since the inclusion of resource based theory (RBT) into some parts of its research stream. In fact, interest in operations strategy has paralleled the growth of interest in resource-based (Wernerfelt, 1984; Barney, 1991; Mahoney and Pandian, 1992) or capability-based (Teece and Pisano, 1994; Teece et al., 1997) models of competitive strategy. The overlaps between operations strategy and resource-based driven views of general strategy are often explicit. Prahalad and Hamel (1990), for example, defined their 'core competencies' as "collective learning....especially how to co-ordinate diverse production skills and integrate multiple streams of technologies". If operations are to play a serious role in helping the firm to stay 'ahead of the game' (Wheelwright and Bowen, 1996) it is vital that operations strategy concepts explore the utility of frameworks, like the RBT, that are increasingly central to mainstream strategic management. However, given that a great deal of operations strategy thought remains functionally defined and subject to within field fragmentation (Skinner 1996a; 1996b) there has also to be further reflection on the comparative insights generated by extant constructs. There has perhaps been insufficient reflection on the underlying conceptualizations and motivations of important models like the order-winning, qualifying model, especially when pragmatic operations strategy frameworks seeks to use them. 


\subsection{How different are the 'operational' and 'strategic' issues in operations?}

It is perhaps because of the tension between operations management's unavoidable responsibilities for day-to-day activities and their strategic role that there appears to be some confusion regarding the nature of strategy in an operations context. Unlike some management functions, operations management and strategy tasks are principally defined by pragmatism and immediacy. Operations must be able to cope with the day-to-day production of goods or delivery of services. This requires practitioners to continually make decisions and implement changes. Similarly, academic operations management and strategy also claims to focus on 'real' managerial preoccupations (Wilson, 1995) and regularly rededicates itself to the needs of practitioners (e.g. Hayes, 2000). Also, the theoretical underpinnings of the operations management and strategy field are somewhat different from other academic management subjects like strategy, marketing or finance. Whereas these fields of study are more-or-less directly connected to base theoretical disciplines such as economics, sociology, psychology and mathematics, OM's underpinnings are more fragmented. Indeed it could be argued that the specific genealogy of 'modern' $\mathrm{OM}$ is a mixture of very different academic inputs (for example, systems theory) and practical fields of application (for example, production engineering). Yet despite the apparently overwhelming practical focus of academic operations management and strategy, it also appears to have a history that demonstrates anxiety about how 'helpful' to operations practice it is really being (Buffa, 1982; Voss, 1995).

The question therefore is whether this pragmatic and practitioner influenced subject can raise itself to the level of abstraction required of any area of study if it is to be truly strategic. But to accept this is to accept that abstraction and aggregation, both of which characterize strategic thinking, is necessarily in conflict with the practical constraints of dynamic and uncertain business life. In fact a stronger argument is that, in dealing with the practicalities of creating services and product, operations strategy of all functions is best placed to reconcile strategic and operational perspectives. Following Mintzberg's concepts of emergent strategy (for example, see Mintzberg, 1987), the operation function should be ideally placed to exploit the day-to-day operational experience that can be the origin of emergent strategies. The implication of this is not that operations, because of its operational role, is unsuited to strategy thought, but rather that it is well positioned to reconcile 'top-down' and 'bottom-up' perspectives on strategy. It also means that the conceptual 'gap' between operations strategy and operations management may be smaller than in other functional areas.

\subsection{Is operations strategy predominantly inside-out, or outside-in?}

Related, but separate, from the 'top-down' or 'bottom-up' debate is the 'internal orientation' or 'external orientation' debate. Put simply, this is essentially a conflict between operations strategy as a functional strategy, and operations strategy as a driver of the business. The increasingly common shorthand for these two perspectives is the 'outside in' as opposed to the 'inside-out' role of operations strategy. The first perspective is perhaps best characterized by the well-known work of Terry Hill, while the second perspective is encapsulated in the more resource-based view of Hayes, Wheelwright and Pisano.

The 'external orientation' of operations strategy starts by identifying existing market requirements and then align operational resources with them (Adam and Swamidass, 1989; Anderson et al., 1989; Platts and Gregory, 1990). This 'outside-in' approach has a number of practical advantages, not least of which is the sheer availability of tools and techniques for classifying and identifying market requirements. Hill's (1984) methodology, for instance, clarifies market order-winners and qualifiers before moving on to discussion of operational processes and infrastructure. These models also fall neatly into a 'traditional' hierarchy of strategies (i.e. corporate, business unit, functional) whereby the role of the operations function is to support pre-determined corporate and market(ing) decisions (Skinner, 1969). However, such 'reactive' operations strategy models have much less explanatory power when discussing long-run competitive advantage based upon pro-active operational excellence (Ferdows and DeMeyer, 1990). Alternatively therefore, operations strategy can begin with the strengths and weaknesses of the operational resources and only then seek market opportunities that fit well with them (Hayes, 1985; Cleveland et al., 1989; Vickery, 1991). Whilst this 'internal' or 'inside-out' model has obvious appeal to operations strategy practitioners and academics, terminological confusion, conceptual ambiguity and a predominantly theoretical orientation have limited its impact on practice (Porter, 1991; Scarborough, 1998; Lewis and Gregory, 1996). Today this 'internal' paradigm, arguing that firm-specific factors are as important (Rumelt, 1987) as industry market factors in determining advantage over time, occupies a central part of the competitive strategy landscape (Foss and Knudsen, 1996). The overlaps between the fields are often explicit, with "core competencies' defined as "collective learning...especially how to co-ordinate diverse production skills and integrate multiple streams of technologies" (Prahalad and Hamel, 1990), and various operational 'behaviours' (Barney and Zajac, 1994).

Although exploitation of strategic resources makes theoretical sense in defining a sustainable competitive 
advantage, these disparate conceptual elements are still characterized by conceptual and terminological ambiguity. Consider for instance, the notion of a set of unique or scarce (or imperfectly mobile, substitutionable etc.) resources. This might appear, at a suitable level of abstraction, to define a very specific set of operational resources, yet there are degrees of scarcity. Equally, such a categorization is prone to market variability: some resources are scarce in a new market without well-defined routes to value creation, whereas established margins enable rivals to justify expenditures that can rapidly eliminate scarcity. The whole issue of the different dynamics associated with each conceptual category in the RBT, a factor that will be crucial in any practical prescription, remains underdeveloped.

By definition, even the most explicitly 'outside-in' operations strategy frameworks do not simply analyse the external environment; they also offer a discussion of how this analysis should influence the operations resource base. The Hill (1984) methodology for instance follows its order-winning, qualifying analysis with a discussion of (stage 4) the correct model of manufacture for specific products (e.g. process choice, volume and variety characteristics etc.) and, (stage 5) the appropriate infrastructure to support the manufacturing processes.

It is perhaps unfair to characterize any author's work as belonging to either the outside-in or the inside-out perspectives exclusively. Most authors do, to some extent, recognize both perspectives even if their work tends to be based in one or the other (usually the outside-in perspective). Indeed, many authors attempt to reconcile both perspectives. Slack and Lewis (2002) go as far as to define operations strategy as the reconciliation between market requirements (outside-in) and operations resource capabilities (inside-out). However, even they make the point that, whereas all businesses have some kind of market to service and therefore must include an outside-in analysis, not all businesses have operations capabilities worth exploiting in a market (the outside-in perspective).

\section{The way forward?}

Although the above discussion presents a number of challenges to the way operations strategy is being researched and practiced, it is possibly one of the most exciting areas of research in business management at the moment. The dynamics of markets and technologies place continual demands on operations strategies. Furthermore, well-known (and often cited) examples such as Dell, IKEA, South West Airlines, Amazon, and so on, all provide evidence that fresh, new, and sometimes radically different operations strategy models can have a huge impact, not only on individual businesses but on whole industries also. Yet, if operations strategy is to continue to provide the intellectual context for the development of such practical models, it must address some of the challenges posed here.

It must stop being an alternative term for manufacturing strategy. Unless academic operations strategy starts to reflect the balance of economic activity, it will become a manufacturing ghetto, increasingly irrelevant as new industries such as telecommunications start to dominate even developing economies.

It must prove relevant to all parts of the business, not just the operations function. This may sound like a paradox, but, if a large part of a firm's resources are engaged in 'non-operations' processes, their contribution must be placed in a strategic context.

Even manufacturing organizations must reconceptualize their view of manufacturing strategy to see it as providing a broad service to its customers who may (or may not) include a manufactured physical product.

It must engage more intimately with some of the development not only in the general strategy area but other areas of management literature. While resource-based theory is clearly of central importance to operations strategy, it has not been fully integrated into operations strategy as yet. Furthermore, there are other areas (for example, real options theory within financial strategy) that have considerable potential for exploitation in the operations strategy area.

It must not conflate the 'top-down or bottom-up' debate with the 'inside-out or outside-in' debate. Many authors assume that top-down is equivalent to outside-in. It is not. The dominant paradigm of market requirements dictating the nature of operations resources can work both at a strategic and operational level. Day-to-day contact with customers is, in practice, a major influence in shaping how businesses articulate their more strategic 'market requirements'.

There are many more perspectives on operations strategy than have been covered here. There are also more debates within the subject over which perspectives and models provide most utility for the development of the subject and its use in practice. So, the issues covered in this paper must be taken very much as a personal view over how the subject needs to change. And, while maintaining that the subject could be made significantly more relevant, it is also important to finish on a more positive note. Operations strategy as a body of knowledge has moved a long way since Skinner's first call for more recognition to be given to the operations (or manufacturing) function. It now represents both an intellectually exciting and practically useful body of knowledge. More significantly, it clearly holds the potential to contribute far more to both theory and practice. 
ADAM, E. E., Jr.; SWAMIDASS, P. E. Assessing operations management from a strategic perspective. Journal of Management, v. 15, n. 2, p. 181-203, 1989.

ANDERSON, J. L., CLEVELAND, G.; SCHROEDER, R. G. Operations Strategy: A Literature Review. Journal of Operations Management, v. 8, n. 2, p. 133-158, April, 1989.

BARNEY, J. Firm Resources and Sustained Competitive Advantage, Journal of Management. v. 17, n. 1, p. 99-120, 1991.

BARNEY, J. B.; ZAJAC, E. D. Competitive Organizational Behavior: Toward an organizationally-based theory of competitive advantage. Strategic Management Journal, v. 15, p. 5-9, winter 1994.

BUFFA, E. S. Research in Operations Management. Journal of Operations Management, v. 1, n. 1, p. 1-7, 1982.

CLEVELAND, G.; SCHROEDER, R. G.; ANDERSON, J.C. A theory of production competence. Decision Sciences, v. 20, n. 4, p. 655-668, 1989.

DREJER, A.; BLACKMON, K.; VOSS, C. Worlds Apart? A look at the OM area in the US, UK and Scandinavia. Scandinavian Journal of Management, v. 16, n. 1, p. 45-66, 2000.

FERDOWS, K.; DEMEYER, A. Lasting Improvements in Manufacturing Performance. Journal of Operations Management, v. 9, n. 2, p. 168-184, 1990.

FOSS, N. J.; KNUDSEN, C. Towards a Competence Theory of the Firm. London: Routledge, 1996.

GADIESH, O.; GILBERT, J. L. Profit Pools: a fresh look at strategy. Harvard Business Review, v. 76, n. 3, p. 139-147, 1998.

HAYES, R. H. Strategic Planning - Forward in Reverse? Harvard Business Review, v. 63, n. 6, p. 56-66, 1985.

. Toward a 'New Architecture' for POM, Production and Operations Management, v. 9, n. 2, p. 105-110, Summer 2000.

HAYES, R. H.; PISANO, G. Manufacturing Strategy: At the Intersection of Two Paradigm Shifts. Production and Operations Management, v. 5, n. 1, p. 25-41, Spring 1996.

HAYES, R. H.; WHEELWRIGHT, S. C. Restoring Our Competitive Edge: Competing Through Manufacturing. Wiley, New York, 1984.

HILL, T. Manufacturing Strategy, MacMillan, Basingstoke, 1984.
LEVITT, T. A Production-Line Approach to Service. Harvard Business Review, v. 50, n. 5, p. 41-52, SeptemberOctober 1972.

LEWIS, M. A.; Gregory, M. J. Developing and Applying a Process Approach to Competence Analysis. In: SANCHEZ, R.; HEENE, A.; THOMAS, H. (eds.), Dynamics of Competence-Based Competition, Elsevier Pergamon, New York, p. 141-164, 1996.

MAHONEY, J; PANDIAN, J. R. The resource-based view within the conversation of strategic management. Strategic Management Journal, v. 13, n. 5, p. 363-380, 1992.

MINTZBERG, H. The strategy concept I: five P's for strategy. Californian Management Review, v. 30, n. 1, p. 11-24, Fall 1987.

MONT, O. Product-Service Systems, International Institute of Industrial Environmental Economics, Lund University Stockholm, Sweden, 2000.

MATHYSSENS, P.; VANDENBEMPT, K. Creating competitive advantage in industrial services. Journal of Business and Industrial Marketing, v. 13, n. 4-5, p. 339-355, 1998.

OLIVA, R.; KALLENBERG, R. Managing the transition from products to services. International Journal of Service Industry Management, v. 14, n. 2, p. 160-172, 2003.

PLATTS, K. W; GREGORY, M. J. Manufacturing Audit in the process of Strategy Formulation. International Journal of Operations and Production Management, v. 10, n. 9 , p. 5-26, 1990.

PORTER, M. E. Towards a Dynamic Theory of Strategy. Strategic Management Journal, v. 12, p. 95-117, Winter 1991.

PRAHALAD, C. K.; HAMEL, G. The core competence of the corporation. Harvard Business Review, v. 68, n. 3, p. 79-91, 1990.

RUMELT, R. Towards a strategic theory of the firm. In: LAMB, R. B. (ed), Competitive Strategic Management, Prentice Hall, Englewood Cliffs, NJ, p. 566-570, 1984.

Theory, strategy and entrepreneurship. In: Teece, D. J. (ed) The Competitive Challenge: Strategies for Industrial Innovation and Renewal. Cambridge, Mass, Ballinger, 1987.

SCARBOROUGH, H. Path(ological) Dependency? Core Competencies from an Organizational Perspective. British Journal of Management, v. 9, n. 3, p. 219-232, 1998. 
SKINNER, W. Manufacturing - Missing Link in Corporate Strategy. Harvard Business Review, v. 47, n. 3, p. 136-145, 1969.

Manufacturing Strategy on the "S" Curve". Production and Operations Management, v. 5, n. 1, p. 3-14, 1996a.

. Three Yards and a Cloud of Dust: Industrial Management at Century End. Production and Operations Management, v. 5, n. 1, p. 15-24, 1996 b.

SLACK, N. Patterns of Servitization: Beyond products and service. Institute for Manufacturing, Cambridge University. London, UK, 2005.

SLACK, N.; LEWIS, M. A. Operations Strategy, Financial-Times Prentice Hall, London, UK, 2001.

Operations Strategy, Prentice Hall, Edinburgh, UK, 2002.

SLACK, N.; LEWIS, M. A.; BATES, H. The two worlds of operations management research and practice: can they meet, should they meet? International Journal of Operations and Production Management, v. 24, n. 4, p. 372-387, 2004.

SLACK, N.; CHAMBERS, S.; JOHNSTON, R.; BETTS, A. Operations and process management: principles and practice for strategic impact. Financial Times Prentice Hall, Harlow, UK, 2006.

TEECE, D.; PISANO, G. The Dynamic Capabilities of Firms: an Introduction. Industrial and Corporate Change, v. 3, n. 3, p. 537-556, 1994.
TEECE, D. J.; PISANO, G.; SHUEN, A. Dynamic Capabilities and Strategic Management. Strategic Management Journal, v. 18, n. 7, p. 509-533, 1997.

VICKERY, S. K. A Theory of Production Competence Revisited. Decision Sciences, v. 22, n. 3, p. 635-643, 1991.

VOSS, C. Operations Management - from Taylor to Toyota - and Beyond. British Journal of Management, v. 6, n. 1, p. 17-29, 1995.

WERNERFELT, B. A Resource-Based View of the Firm. Strategic Management Journal, v. 5, n. 2, p. 171-180, 1984.

WHEELWRIGHT, S. C.; BOWEN, K. The Challenge of Manufacturing Advantage. Production and Operations Management, v. 5, n. 1, p. 59-77, 1996.

WHITE, A. L.; STOUGHTON, M., FENG, L. Servicising: the Quiet Transition to Extended Product Responsibility. Tellus Institute. Boston, MA, 1999.

WILSON, J. M. An Historical Perspective on Operations Management. Production and Inventory Management Journal, v. 36, n. 3, p. 61-66, 1995.

WISE, R.; BAUMGARTNER, P. Go downstream: the new imperative in manufacturing. Harvard Business Review, v. 77, n. 5, p. 133-141, 1999.

WOMACK, J. P.; JONES, D. T. From Lean Production to the Lean Enterprise. Harvard Business Review, v. 72, n. 2, p. 93-103, 1994.

. Lean Thinking, Simon and Schuster, New York, NY, 1996.

\section{ESTRATÉGIA DE OPERAÇÕES: ELA NUNCA REALIZARÁ O SEU POTENCIAL?}

\section{Resumo}

Embora nas últimas três décadas tenha sido constatado um constante crescimento na percepção de importância da área de estratégia de operações, juntamente com a sua respectiva base literária, pode-se argumentar que ela ainda não atingiu todo o seu potencial. Este artigo revisa algumas das razões pelas quais isto pode estar ocorrendo. Inicialmente, a importância da estratégia de operações dentro da área mais ampla de gestão de operações é analisada de forma sucinta e em seguida, alguns desafios são explorados em duas vertentes. A primeira trata se estratégia de operações reflete precisamente a natureza das operações dentro da economia. A segunda explora alguns dos desafios em tornar tópicos relacionados a operações em tópicos com importância estratégica. Por fim, são propostas algumas prescrições que podem apoiar o desenvolvimento da área de modo a responder a alguns dos desafios apresentados.

Palavras-chave: estratégia de operações, operações em manufatura, operações em serviços, tendências de pesquisa. 